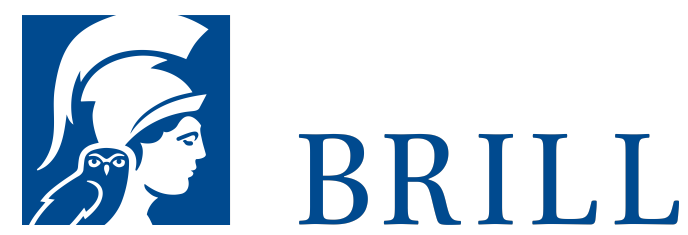

\title{
Hedonismus und das gute Leben
}

\section{Author: Andreas Bachmann}

Die Frage nach dem guten Leben ist eine Grundfrage der Philosophie. Eine klassische Antwort liefert der Hedonismus: Ein gutes Leben ist ein Leben, das überwiegend aus lustvollen Erfahrungen besteht. Dieser Antwort wurde immer schon mit großen Vorbehalten begegnet. Dem Hedonismus wurde und wird vorgehalten, er rede einer egoistischen Lebenshaltung der Lustmaximierung das Wort und setze den Menschen durch die Reduktion des Guten auf Lust dem Tier gleich. Dieser Reduktionismus habe zudem zutiefst kontraintuitive und damit inakzeptable Implikationen. Ihm zufolge komme es nur darauf an, ob sich eine Erfahrung gut oder schlecht anfühlt, unabhängig davon, ob sie eine Basis in der Realität hat oder lediglich auf Einbildung beruht. "Hedonismus und das gute Leben" zeigt auf, warum diese Kritik unberechtigt ist und warum es gute Gründe für den Hedonismus gibt. Vor allem, wenn die Frage nach dem guten Leben ohne Rückgriff auf metaphysische oder religiöse Annahmen beantwortet werden soll.

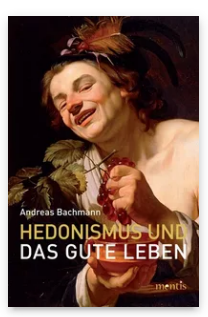

Pages: 390

Seiten

Language:

German

Subjects:

General,

Philosophy

Publisher: Brill | mentis

E-Book (PDF)

Released online:

o1 Feb 2013

ISBN: 978-3-

89785-962-3

List price

Paperback

Publication date: o1 Feb 2013

ISBN: 978-389785-795-7

List price 
For more information see brill.com

Order information: Order online at brill.com +44330 333 0049 | customerservices@brill.com Submission information: brill.com/authors

Titles published by Brill | Fink, Brill | mentis or Brill | Schöningh: +49(o)715413279216| brill@brocom.de 